\title{
PHÂN TÍCH SWOT SẢN XUÂT CAM SÀNH Ở TỈNH TUYÊN QUANG TRONG XU THẾ HỘI NHẬP
}

\section{Swot analysis of orange production in Tuyen Quang province towards intergration}

Ngày 08/6/2016; ngày phản biện: 22/2/2017; ngày duyệt đăng: 22/3/2017

Trần Thị Diên*

\section{TÓM TẮT}

Bài viết sử dụng phương pháp phân tích SWOT để đánh giá điểm mạnh (Strengths), điểm yếu (Weaknesses), cơ hội (Opportunities) và thách thức (Threats) trong sản xuất cam sành ở tỉnh Tuyên Quang trong xu thế hội nhập. Phân tích SWOT cho thấy sản xuất cam sành ở tỉnh Tuyên Quang có nhiều thế mạnh. Nhưng bên cạnh đó vẫn còn những khó khăn, hạn chế cần tháo gỡ. Quá trình hội nhập kinh tế quốc tế tạo ra cơ hội lớn cho phát triển sản xuất cam sành, nhưng người trồng cam cũng phải đối mặt với không ít những thách thức cho sự phát triển. Qua đó, tác giả đề xuất một số giải pháp nhằm thúc đẩy phát triển sản xuất cam sành của tỉnh Tuyên Quang theo hướng hội nhập. Để sản phẩm cam sành Tuyên Quang thực sự trở thành sản phẩm có thương hiệu nổi tiếng, có thể phát triển sản xuất với quy mô lớn, khối lượng hàng hóa nhiều, đáp ứng được nhu cầu tiêu thụ trong nước và xuất khẩu.

Từ khóa: cam sành; giải pháp phát triển; hội nhập; phân tích SWOT; Tuyên Quang.

\section{ABSTRACT}

The article used SWOT analysis method to assesses the strengths (S), weaknesses (W), opportunities $(\mathrm{O})$ and threats $(\mathrm{T})$ in orange production in Tuyen Quang province in the integration trend. Analysis by SWOT shows that orange production in Tuyen Quang province has many advantages. Beside, there are many difficulties and limitations that need solving. The process of international economic integration creates great opportunities for development of orange production, but also the farmers are faced with many challenges for development. Thereby, the author give solutions to promote the development of orange production in Tuyen Quang province towards integration. For Tuyen Quang oranges actually become famous brand products, with largescale production, volume of goods more and more, to meet domestic demand and exports.

Keywords: orange; development solutions; integration; SWOT analysis; Tuyen Quang.

\section{Đặt vấn đề}

Toàn cầu hóa, hội nhập kinh tế quốc tế và tự do hóa thương mại đang là xu hướng tất yếu của nền kinh tế thế giới. Hòa chung xu thế, Việt Nam đã tiến hành công cuộc đổi mới và đẩy mạnh hội nhập kinh tế quốc tế với phương châm "đa dạng hóa, đa phương hóa" quan hệ đối ngoại, chủ động và tích cực mở rộng hợp tác quốc tế trên nhiều lĩnh vực. Đến nay, Việt Nam đã tham gia nhiều hiệp định thương mại tự do, điều này sẽ tạo điều kiện cho nông sản Việt Nam gia tăng sản xuất và mở rộng thị trường xuất khẩu đi khắp thế giới [4].

Tuyên Quang là một tỉnh miền núi phía Bắc của Việt Nam, nền kinh tế nông - lâm nghiệp chiếm ưu thế. Tỉnh có các điều kiện về tự nhiên, kinh tế, xã hội thuận lợi và thích hợp cho việc phát triển sản xuất một số nông sản đặc trưng, đặc biệt là cây cam sành. Quả cam sành là một trong những trái cây có giá trị dinh 
dưỡng cao, rất có lợi cho sức khỏe, ngoài công dụng phổ biến là một loại thực phẩm, nước giải khát, cam sành còn có nhiều tác dụng chữa bệnh [9]... Đối với tỉnh Tuyên Quang, cam sành là cây ăn quả có giá trị kinh tế cao, là loại cây trồng có vị trí quan trọng trong đời sống sinh hoạt cũng như phát triển kinh tế và văn hóa con người. Việc phát triển sản xuất cây cam sẽ đưa giá trị của ngành nông nghiệp tăng lên, đáp ứng nhu cầu ngày càng cao về sản phẩm quả tươi có chất lượng đối với người tiêu dùng. Việc chuyển đổi diện tích một số cây trồng khác có năng suất, chất lượng thấp sang trồng cam sành sẽ tạo những vùng chuyên môn hóa sản xuất cam hàng hóa, tạo điều kiện để thực hiện đồng bộ các giải pháp về sản xuất, thu hoạch, chế biến, bảo quản và tiêu thụ. Có như vậy mới gia tăng được giá trị của quả cam, mang lại thu nhập cao cho người nông dân vùng trồng cam, thúc đẩy phát triển sản xuất nông nghiệp theo hướng hàng hóa.

\section{Phương pháp nghiên cứu}

Ma trận SWOT có cấu trúc sau:

\begin{tabular}{|c|c|c|}
\hline $\begin{array}{l}\text { PHÂN TÍCH } \\
\text { SWOT }\end{array}$ & $\begin{array}{l}\text { TÍCH CỰC } \\
\text { /CÓ LỢI }\end{array}$ & $\begin{array}{l}\text { TIÊU CỰC } \\
\text { /GÂYY HẠI }\end{array}$ \\
\hline $\begin{array}{l}\text { TÁC NHÂN } \\
\text { BÊN TRONG } \\
\text { (Sự thật, yếu } \\
\text { tố... phát sinh } \\
\text { từ nội bộ) }\end{array}$ & $\begin{array}{c}\text { ĐIÊMM MẠNH } \\
\text { (STRENGTHS) } \\
\text { Cần phải được } \\
\text { duy trì, sử dưng } \\
\text { chúng làm đòn } \\
\text { bẩy. }\end{array}$ & $\begin{array}{l}\text { ĐIỂM YẾ } \\
\text { (WEAKNESSES) } \\
\text { Cần phải được sữa } \\
\text { chữa, thay thế hoặc } \\
\text { chấm dứt. }\end{array}$ \\
\hline $\begin{array}{l}\text { TÁC NHÂN } \\
\text { BÊN NGOÀI } \\
\text { (Sự thật, yếu } \\
\text { tố... phát sinh } \\
\text { từ môi trường } \\
\text { xung quanh) }\end{array}$ & $\begin{array}{c}\text { CƠ HỒI } \\
\text { (OPPOTUNITIE } \\
\underline{\text { S) }} \\
\text { Cần phải được } \\
\text { tận dụng, ưu tiên, } \\
\text { nắm bắt kịp thời, } \\
\text { xây dựng và phát } \\
\text { triển trên những } \\
\text { cơ hội này. }\end{array}$ & $\begin{array}{l}\text { THÁCH THỨC } \\
\text { (THREATS) } \\
\text { Cần phải đưa ra } \\
\text { các phương án } \\
\text { phòng bị, giải } \\
\text { quyết, đâyy lùi nguy } \\
\text { cơ, vượt qua thách } \\
\text { thức. }\end{array}$ \\
\hline
\end{tabular}

Phân tích SWOT trong sản xuất cam sành ở tỉnh Tuyên Quang nhằm đánh giá những điểm mạnh, điểm yếu nội tại, đồng thời phân tích được những cơ hội và thách thức đặt ra trong tương lai trong tiến trình phát triển kinh tế, hội nhập khu vực và thế giới. Từ đó đưa ra những giải pháp nhằm phát huy điểm mạnh, tranh thủ cơ hội, khắc phục các điểm yếu, vượt qua thách thức, giảm thiểu các nguy cơ để phát triển sản xuất cam sành theo hướng hàng hóa trên địa bàn nghiên cứu. Việc phân tích, đánh giá nhằm đề ra các giải pháp hướng đến mục tiêu sản phẩm cam sành của tỉnh có thể đáp ứng nhu cầu sản xuất và tiêu dùng trong tỉnh, trong nước, đồng thời có đủ sức cạnh tranh để vươn ra thị trường khu vực và thế giới.

\section{Sơ lực tình hình phát triển sản xuất}

\section{cam sành ở tỉnh Tuyên Quang}

Tỉnh Tuyên Quang có tổng diện tích đất tự nhiên là 586.733 ha, trong đó diện tích đất nông lâm nghiệp chiếm 90,5\%. Năm 2015, dân số của toàn tỉnh khoảng 760.000 người, trong đó dân số nông thôn chiếm 86,6\%. Trong những năm qua, tỉnh Tuyên Quang đã đạt được những thành tựu về phát triển kinh tế - xã hội: an ninh lương thực được đảm bảo; tốc độ tăng trưởng GDP giai đoạn 2010 - 2015 đạt trên $14 \%$; từng bước chuyển dịch cơ cấu kinh tế, cơ cấu cây trồng, vật nuôi theo hướng sản xuất hàng hoá. Phát triển nông nghiệp theo hướng sản xuất hàng hóa tập trung được xác định là bước đi quan trọng để đưa khu vực nông thôn Tuyên Quang sớm thoát khỏi tình trạng kém phát triển, nâng cao thu nhập cho người dân [2]. Đến nay, tỉnh Tuyên Quang đã hình thành được các vùng sản xuất hàng hóa tập trung, gồm 8.747 ha chè, 11.611 ha mía, 5.491 ha cam, 4.374 ha lạc, gần 1.000 ha chuối, 129.000 ha rừng trồng nguyên liệu[5]. Với tài nguyên đất khá đa dạng về nhóm và loại nên tỉnh có nhiều tiểu vùng sinh thái nông - lâm nghiệp thích hợp với nhiều loại cây trồng. Đối với diện tích đất phù hợp với phát triển trồng cây ăn quả, thì cam sành là loại cây trồng đang chiếm ưu thế.

Cam sành là loại cây bản địa đã được trồng từ nhiều đời nay tại các huyện Hàm Yên, 
Chiêm Hoá và là một trong những loài cây trồng thế mạnh của tỉnh, có giá trị kinh tế cao, mang lại nguồn thu nhập cao và ổn định cho người dân, giúp xoá đói giảm nghèo, giải quyết được nhiều việc làm cho lao động nông thôn, góp phần thúc đẩy phát triển nền kinh tế của tỉnh. Đến năm 2015, diện tích cam của toàn tỉnh đạt trên 5000 ha, sản lượng đạt trên 43.000 tấn/năm, với trên 4.000 hộ trồng cam [5].

Tuy nhiên, quá trình phát triển cây cam vẫn còn nhiều hạn chế về giống, kỹ thuật, chất lượng sản phẩm, sản lượng hàng hóa, cơ sở vật chất, kỹ thuật thu hoạch, bảo quản, chế biến, thương hiệu sản phẩm và thị trường tiêu thụ. Tình trạng “được mùa, mất giá” vẫn diễn ra thường xuyên. Nhiều khó khăn vẫn chưa được giải quyết như: bảo quản sản phẩm sau thu hoạch; xây dựng nhà máy chế biến; việc phát triển sản xuất vẫn theo hướng tự phát; vấn đề xây dựng thương hiệu, mở rộng thị trường tiêu thụ trong và ngoài nước...

3. Phân tích SWOT đối với sản xuất cam sành của tỉnh Tuyên Quang trong xu thế hội nhập

\section{1. Điểm mạnh (Strengths)}

- Điều kiện tư nhiên thuận lợi cho phát triển sản xuất cam sành: Vùng sản xuất cam tập trung nằm ở phía Bắc tỉnh Tuyên Quang gồm 15 xã thuộc 2 huyện Hàm Yên và Chiêm Hoá, nằm trên trục đường quốc lộ 2 và đường tỉnh lộ rất thuận lợi cho việc lưu thông trao đổi hàng hoá. Đây là vùng có khí hậu nhiệt đới gió mùa, lượng mưa trung bình hàng năm 1.600 $1.800 \mathrm{~mm}$, số ngày mưa trung bình 150 ngày/năm, trên địa bàn có nhiều suối lớn và sông Lô chảy qua, là nguồn cung cấp nước phục vụ cho sản xuất. Ngoài ra vùng này có chế độ mưa và chế độ nhiệt thích hợp cho việc phát triển các loại cây ăn quả, đặc biệt là cây cam sành [9].
- Lực lương lao động dồi dào, chi phí nhân công rẻ: Trong cơ cấu kinh tế của tỉnh Tuyên Quang thì nông nghiệp vẫn là ngành kinh tế chiếm tỷ trọng cao. Lực lượng lao động tham gia sản xuất nông nghiệp dồi dào, với $72,6 \%$ người trong độ tuổi lao động làm ngành nông nghiệp. Thêm vào đó, tiền công lao động trong lĩnh vực nông nghiệp rẻ nên sản xuất nông nghiệp nói chung cũng như sản xuất cây cam nói riêng ở tỉnh đang có lợi thế về lao động dồi dào, nhân công giá rẻ.

- Cam sành cho năng suát, sản luợng, giá trị cao: Các hộ trồng cam đã nhận thức được giá trị thương hiệu của sản phẩm cam sành Hàm Yên, không ngừng đầu tư thâm canh, phòng trừ dịch hại, chú trọng ứng dụng tiến bộ khoa học, kỹ thuật vào trong sản xuất, làm cho chất lượng cam quả và mẫu mã đã dần được cải thiện, năng suất tăng từ 50 tạ/ha năm 2000 lên 76 tạ/ha năm 2008, năm 2014 đạt 120 tạ/ha. Năm 2015, tổng sản lượng toàn tỉnh đạt trên 43.000 tấn, thu nhập đạt trên 430 tỷ đồng (giá cam bình quân là 10.000 đồng $/ \mathrm{kg}$ ). Trung bình mỗi hộ trồng cam có thu nhập trên 100 triệu đồng/ năm [7].

- Nguoòi dân có kinh nghiệm trồng cam: Ở mỗi vùng địa hình và khí hậu khác nhau thì cây cam cũng cần có chế độ chăm sóc khác nhau. Ngoài các yếu tố về giống, áp dụng các tiến bộ khoa học kỹ thuật vào trong sản xuất, thì kinh nghiệm đúc kết truyền từ đời này sang đời khác áp dụng vào sản xuất là yếu tố hết sức quan trọng để nâng cao năng suất, chất lượng và hiệu quả, phát triển thương hiệu sản phẩm. Cam sành là loại cây trồng bản địa đã được người dân trồng từ nhiều đời nay trên địa bàn tỉnh, vậy nên một trong các yếu tố là thế mạnh của vùng đối với sản xuất cam sành là kinh nghiệm truyền đời của các hộ trồng cam.

- Sản phẩm cam sành Hàm Yên đã có thuoong hiệu nổi tiếng cả nước:Năm 2007, 
huyện Hàm Yên đã xây dựng thành công thương hiệu "Cam sành Hàm Yên". Hàm Yên có điều kiện tự nhiên về đất đai, khí hậu phù hợp cho cây cam sành sinh trưởng và phát triển, người dân có kinh nghiệm trồng lâu năm. Cam sành Hàm Yên là loại cây trồng chủ lực có từ lâu đời của huyện, được trồng nhiều trên vùng đồi núi và là loại quả có giá trị dinh dưỡng rất cao. Nhờ vậy, cam sành Hàm Yên đã được bình chọn là 1 trong 50 loại trái cây đặc sản Việt Nam, Top 10 thương hiệu - nhãn hiệu nổi tiếng do Tạp chí Sở hữu Trí tuệ và Sáng tạo bình chọn, gần đây nhất vào ngày 17/5/2014 được tôn vinh là một trong những sản phẩm nông nghiệp tiêu biểu 2013 [5].

\section{"Hàm Yên lịm ngọt huơng cam"}

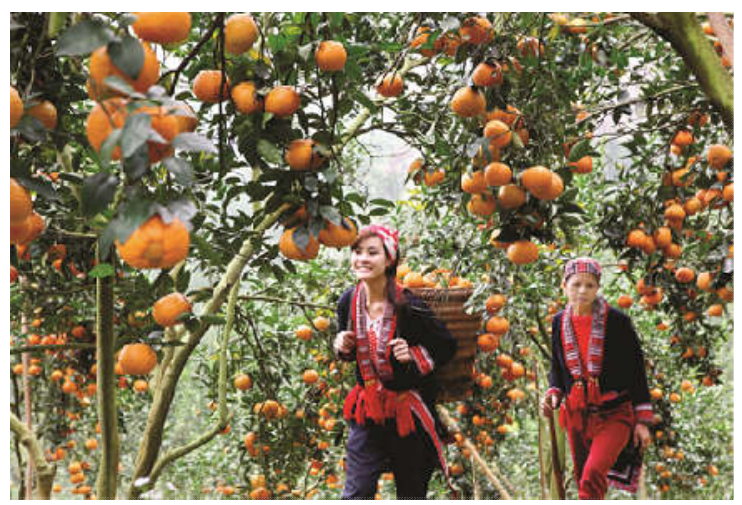

Anh: Nguyễn Chính

( nguồn: http://www.baotuyenquang.com.vn/)

- Về quy hoạch, chính sách phát triển vùng sản xuất cam tập trung: Năm 2014, UBND tỉnh Tuyên Quang đã phê duyệt đề án quy hoạch phát triển vùng sản xuất cam sành tỉnh Tuyên Quang giai đoạn 2014 - 2020, quy hoạch bổ sung trên 3.900 ha để hình thành vùng sản xuất cam sành tập trung của tỉnh Tuyên Quang với quy mô diện tích trên 6.800 ha. Trước mắt, phát triển diện tích cam sành toàn vùng đến năm 2020 đạt trên 5.000 ha, trong đó trồng mới 1.100 ha. Nâng năng suất bình quân đạt trên 150 tạ/ha, sản lượng đạt trên 65.000 tấn; giá trị đạt trên 1.300 tỷ đồng [7]. Những quy hoạch và chính sách phát triển vùng sản xuất cam tập trung của các cấp chính quyền trên địa bản tỉnh cho thấy sự quan tâm, chỉ đạo, định hướng, hỗ trợ phát triển đối với sản xuất cam sành, nhằm phát huy tiềm năng, lợi thế của tỉnh đối với sản phẩm cam sành.

\section{2. Điểm yếu (Weaknesses)}

Bên cạnh những điểm mạnh tạo nên lợi thế cho phát triển sản xuất cam sành theo hướng hội nhập, thì còn rất nhiều khó khăn, hạn chế cần phải tháo gỡ, đó là:

- Hoạt động sản xuất còn mang tính thủ công, tư phát: Nhiều khâu trong quá trình sản xuất còn mang tính thủ công, đầu tư chưa đầy đủ, sản xuất phụ thuộc nhiều vào các yếu tố tự nhiên nên năng suất lao động chưa cao, sản lượng không đều, năm thì được mùa, năm thì mất mùa, dẫn đến gặp khó khăn trong việc ký kết các hợp đồng tiêu thụ với các nhà máy chế biến và đối tác xuất khẩu nước ngoài.Việc mở rộng diện tích trồng cam của các hộ gia đình còn mang tính tự phát, theo phong trào nên tiềm ẩn nhiều rủi ro nếu không gắn với chế biến, mở rộng thị trường tiêu thụ sản phẩm và tăng cường công tác quản lý chất lượng, giữ vững thương hiệu.

- Nguồn lục đầu tu cho sản xuất còn thiếu và chura đồng bộ: Các nguồn lực đầu tư cho sản xuất, kinh doanh cam sành còn nhỏ lẻ, manh mún. Hệ thống cơ sở hạ tầng, máy móc thiết bị, công nghệ sản xuất và thu hoạch còn thiếu. Thiếu các công cụ dụng cụ, máy móc thiết bị hỗ trợ sản xuất như máy làm đất, máy bón phân, máy bơm tưới, máy cắt tỉa, hệ thống ròng rọc, cáp treo để thu hoạch sản phẩm; thiếu kho tàng để tạm trữ sản phẩm sau thu hoạch, thiếu nhà mát để lưu kho; nhà máy chế biến sản phẩm chưa có; vật liệu bao bì vận chuyển sản phẩm chưa tốt gây tổn thất lớn trong thu hoạch, bảo quản và tiêu thụ, làm giảm chất lượng sản phẩm.

- Chất lương sản phẩm chura được quản lý nghiêm ngặt: Vẫn còn một bộ phận các hộ 
trồng cam sản xuất sản phẩm chưa thực sự quan tâm đến vệ sinh an toàn thực phẩm, bảo vệ môi trường sinh thái và phát triển bền vững. Việc sử dụng phân bón hóa học, thuốc trừ sâu, thuốc diệt cỏ,thuốc kích thích sinh trưởng, thuốc bảo quản một cách tùy tiện, vượt quá giới hạn cho phép, dẫn đến thoái hóa đất, ô nhiễm môi trường, gây hại sức khỏe cho công đồng, làm mất niềm tin của người tiêu dùng. Sự lẫn lộn giữa cam sản xuất theo tiêu chuẩn VietGap và cam không rõ nguồn gốc gây nghi ngại cho người tiêu dùng.

- Yếu kém trong khâu thu hoạch, bảo quản, chế biến: Khâu thu hoạch còn mang tính ồ ạt, thủ công, không đúng quy trình dẫn đến sản phẩm bị xây xát, dập nát nhiều, tỉ lệ sản phẩm nhanh bị hỏng, thối cao. Người thu hái phải trèo lên cây cao. Nhiều vườn cam ở trên đồi cao, đất dốc, việc thu hái sản phẩm chưa có công cụ hỗ trợ dẫn đến tốn nhiều công sức, sự va chạm nhiều làm sản phẩm bị hỏng. Hệ thống nhà kho lạnh để bảo quản sản phẩm còn thiếu, sản phẩm thu hái là bán luôn dẫn đến tình trạng bị ứ đọng, tính mùa vụ cao, khó tiêu thụ và bị ép giá.

- Chura xây dụng được chuỗi giá trị ngành hàng "tù trang trại đến bàn ăn": tình trạng sản phẩm thu hoạch bán trôi nổi trên thị trường, không tem mác, không nguồn gốc xuất xứ nên chưa tạo được niềm tin cho người tiêu dùng khi sử dụng sản phẩm. Và khi lượng cam sành thu hoạch chính vụ đạt điểm đỉnh với khối lượng hàng hóa lớn thì nông dân gặp khó khăn trong tiêu thụ sản phẩm.

- Khó khăn trong tiêu thu sản phẩm: Thi trường đầu ra cho sản phẩm không ổn định, bởi tất cả các khâu từ sản xuất, thu hoạch, bảo quản, chế biến, xây dựng thương hiệu, tiêu thụ nông sản đều thiếu sự quy hoạch, thiếu tính chiến lược, thiếu sự đồng bộ và thiếu sự đầu tư thỏa đáng ... gây ra những bất ổn và rủi ro đối với việc sản xuất và tiêu thụ sản phẩm.

\subsection{Co' hội (Opportunities)}

- Co hội mở rộng thị truờng xuất khẩu: Khi Việt Nam tham gia các hiệp định thương mại tự do, hàng loạt các hàng rào thuế quan và phi thuế quan được gỡ bỏ, các mặt hàng nông sản của Việt Nam nói chung và sản phẩm cam sành của tỉnh Tuyên Quang nói riêng có cơ hội được xuất khẩu ra các nước trên khắp thế giới. Sản phẩm sẽ thu được giá trị cao mang lại lợi ích lớn cho người trồng cam và thu nguồn ngoại tệ cho đất nước [4].

- Co hội tăng cường các nguồn lực cho đầu tur phát triển: Hội nhập kinh tế quốc tế sẽ tạo ra các dòng dịch chuyển tự do các nguồn lực cho phát triển sản xuất như: lao động, vốn, khoa học kỹ thuật, máy móc thiết bị, trình độ quản lý... Khi thu hút được các nguồn lực sẽ mở rộng được quy mô sản xuất kinh doanh hàng hóa nông sản ở tất cả các khâu: sản xuất, thu hoạch, chế biến, tiêu thụ. Đối với việc phát triển sản xuất cam sành của Tuyên Quang theo hướng hàng hóa, nhu cầu đối với các nguồn lực này đang hết sức cần thiết.

- Co hội liên doanh, liên kết, hợp tác quốc tế: Các nhà đầu tư nước ngoài sẽ hợp tác với người dân, doanh nghiệp Việt nam để cùng thực hiện các hoạt động sản xuất kinh doanh sản phẩm trong các lĩnh vực. Chúng ta có lợi thế về điều kiện tự nhiên, đất đai, lao động, còn các nhà đầu tư nước ngoài sẽ mang đến các nguồn lực cần thiết khác như vốn, khoa học kỹ thuật, trình độ quản lý... Chúng ta sẽ có đủ nguồn lực để phát triển sản xuất còn các nhà đầu tư nước ngoài sẽ thúc đẩy quá trình bảo quản, chế biến và tiêu thụ (xuất khẩu) sản phẩm. Quá trình phát triển dựa trên sự hợp tác, đôi bên cùng có lợi.

- Co hội úng dụng tiến bộ khoa học kỹ thuật vào sản xuất: Hội nhập sẽ góp phần tăng 
cường nghiên cứu, ứng dụng khoa học - kỹ thuật - công nghệ hiện đại, tiên tiến vào sản xuất, chế biến và tiêu thụ nông sản nhằm đảm bảo năng suất, chất lượng và hiệu quả kinh tế. Tập trung phát triển sản xuất nông nghiệp theo hướng hữu cơ, nông nghiệp sinh thái bền vững. Đầu tư phát triển cơ sở hạ tầng phục vụ phát triển nền nông nghiệp sản xuất hàng hóa. Đẩy mạnh công nghệ sau thu hoạch.

- Co hội nâng cao chất lương nguồn nhân lực: Nguồn nhân lực chất lượng cao đang là nhu cầu thiết yếu cho mọi lĩnh vực, là nền tảng cho sự phát triển. Quá trình hội nhập sẽ tạo ra luồng dịch chuyển lao động tự do giữa các nước và cơ hội hợp tác đào tạo nguồn nhân lực chất lượng cao cho các ngành nói chung và cho sản xuất nông sản hàng hóa nói riêng. Khi có đủ tiềm lực,việc thu hút người tài trong nước và nước ngoài, hay việc hợp tác đào tạo nguồn nhân lực phục vụ cho sự phát triển sẽ trở nên thuận lợi, dễ dàng.

\subsection{Thách thức (Threats)}

- Yêu cầu cao về chất lương sản phẩm: Hàng loạt các tiêu chuẩn được đặt ra đối với sản phẩm hội nhập của Việt Nam. Khi các hàng rào thuế quan gỡ bỏ, cũng là lúc các hàng rào phi thuế quan đặt ra nghiêm ngặt hơn. Các tiêu chuẩn yêu cầu đối với nông sản về chất lượng, thương hiệu, vệ sinh an toàn thực phẩm, kiểu dáng mẫu mã, nguồn gốc xuất xứ, nhãn hiệu, bản quyền, quyền sở hữu trí tuệ, chống bán phá giá... hàng loạt các vấn đề rất mới mà người trồng cam vẫn còn lúng túng. Nếu sản phẩm cam sành không đáp ứng được các yêu cầu nghiêm ngặt của hàng rào phi thuế quan (các rào cản kỹ thuật) thì sẽ không hướng đến được thị trường xuất khẩu.

- Yêu cầu về sản luợng cam hàng hóa nhiều, ổn định: Khi hướng sản phẩm đến thị trường xuất khẩu, cần ký kết được các hợp đồng tiêu thụ với các doanh nghiệp xuất khẩu cùng khối lượng cam sành đủ lớn và ổn định. Trong khi mỗi một hộ trồng cam là cá thể sản xuất nhỏ lẻ, độc lập, manh mún và tự phát. Rất khó có thể gom được một lượng hàng hóa lớn, tập trung, đồng đều về chất lượng, hình thức, mẫu mã. Việc xây dựng các nhà máy bảo quản, chế biến là cần thiết cho phát triển vùng sản xuất cam hàng hóa tập trung nhưng cũng đứng trước thách thức rất lớn là không đủ lượng nguyên liệu đầu vào, hoặc sản lượng không ổn định, giá cả bấp bênh và tính mùa vụ cao trong sản xuất dẫn đến những khó khăn trong hoạt động của các nhà máy chế biến.

- Cạnh tranh gay gắt: Quá trình hội nhập sẽ tạo ra thị trường chung, không còn rào cản hàng hóa, dịch vụ, vốn... Hàng hoá ở các nước thành viên hiệp định tự do thương mại sẽ có mức thuế ưu đãi như nhau, khi đó sức cạnh tranh sẽ tập trung vào chất lượng và giá trị gia tăng của sản phẩm. Hơn nữa, việc cạnh tranh lại diễn ra ngay trên sân nhà, khi mà các loại sản phẩm cùng loại có chất lượng cao, hình thức mẫu mã đẹp, giá cả thấp hơn do hàng rào thuế quan đã gỡ bỏ, nông sản nước ngoài dễ dàng thâm nhập vào Việt Nam và cạnh tranh với nông sản trong nước.

- Sự chênh lệch về trình độ phát triển: So với các nước thành viên của các hiệp định tự do thương mại mà Việt Nam đã tham gia ký kết, nước ta vẫn là một nước nghèo, trình độ khoa học công nghệ còn lạc hậu, quy mô về vốn cho sản xuất kinh doanh con thiếu, tay nghề lao động chưa cao, nhận thức của người sản xuất (đặc biệt là nông dân) về kinh tế thị trường, hội nhập quốc tế, văn hóa thương mại... còn rất hạn chế. Các chủ thể sản xuất kinh doanh nông sản hàng hóa của Việt Nam còn rất nhỏ bé cả về quy mô hoạt động, năng lực tài chính, trình độ, kinh nghiệm quản lý điều hành. Đây thực sự là thách thức lớn trong tiến trình hội nhập, nếu không vượt được qua chúng ta sẽ "thua ngay trên sân nhà". 
- Thách thức đặt ra đối với quyền làm chủ sản xuất của nông dân: Khi tham gia các hiệp định thương mại tự do cũng có nghĩa các thương lái nước ngoài có quyền thu mua trực tiếp nông sản của Việt Nam ngay trên đồng ruộng. Nhà đầu tư nước ngoài có thể tham gia và chi phối toàn bộ quá trình sản xuất kinh doanh từ khâu cung ứng đầu vào, giống, quy trình sản xuất, vốn, kỹ thuật, đến khâu thu hoạch, bảo quản, chế biến và tiêu thụ. Khi đó, doanh nghiệp nước ngoài có thể điều phối diện tích sản xuất và sản lượng sản phẩm. Nông dân có thể trở nên bị động trong sản xuất và tiêu thụ sản phẩm. Thương lái nước ngoài có thể chi phối giá cả sản phẩm, ép giá, hạ giá dẫn đến nông dân không có lợi nhuận, từ bỏ sản xuất hoặc trở thành người làm thuê trên chính đồng ruộng của mình.

\section{4. Đề xuất giải pháp thúc đẩy hội nhập cho sản phẩm cam sành của tỉnh Tuyên Quang}

4.1. Phát huy thế mạnh: Khai thác tiềm năng, thế mạnh về điều kiện tự nhiên, kinh tế, xã hội của tỉnh để phát triển vùng sản xuất cam sành:

- Quy hoạch mở rộng vùng sản xuất cam sành.

- Thu hút lực lượng lao động tham gia vào quá trình sản xuất, đặc biệt là nguồn nhân lực có trình độ cao.

- Tiếp tục áp dụng các biện pháp khoa học kỹ thuật vào sản xuất nhằm nâng cao năng suất, sản lượng và chất lương sản phẩm cam.

- Chú trọng đến kinh nghiệm trồng cam của những người dân bản địa.

- Tiếp tục xây dựng và giữ vững thương hiệu "Cam sành Hàm Yên"

- Các cấp chính quyền tiếp tục quan tâm, có những chính sách định hướng, hỗ trợ cho phát triển vùng sản xuất cam sành.

\subsection{Khắc phục khó khăn}

- Tổ chức các hình thức sản xuất kinh doanh phù hợp, có quy hoạch, kế hoạch, định hướng và đầu tư cho quá trình phát triển, tránh tình trạng sản xuất mang tính thủ công, tự phát, phong trào.

- Đầu tư các nguồn lực cho phát triển sản xuất một cách đầy đủ và đồng bộ. Đầu tư cơ sở hạ tầng phục vụ phát triển sản xuất như hệ thống cáp treo cho thu hoạch sản phẩm, hệ thống máy bơm, tưới, hệ thống máy làm đất, bón phân. Đẩy mạnh công nghệ sau thu hoạch như xây dựng hệ thống nhà kho lạnh, ứng dụng công nghệ bảo quản, đầu tư nhà máy chế biến nước ép quả và các sản phẩm từ quả cam...

- Quản lý nghiêm ngặt chất lượng sản phẩm. Chú trọng đến nhu cầu, thị hiếu và lợi ích sức khỏe của người tiêu dùng.

- Trang bị máy móc, thiết bị, áp dụng kỹ thuật, công nghệ vào khâu thu hoạch, bảo quản sản phẩm. Xây dựng nhà máy chế biến các sản phẩm từ cam sành nhằm gia tăng giá trị sản phẩm. Phát triển công nghiệp sản xuất các tư liệu sản xuất phục vụ cho sản xuất nông nghiệp (máy móc, thiết bị, phân bón, thuốc BVTV, quy trình kỹ thuật sản xuất...). Phát triển các doanh nghiệp thu mua, bảo quản, chế biến, tiêu thụ sản phẩm trong nước và xuất khẩu.

- Xây dựng được chuỗi giá trị ngành hàng "từ trang trại đến bàn ăn". Kết hợp chặt chẽ trong tất các khâu hình thành nên chuỗi giá trị sản phẩm: sản xuất, thu hoạch, bảo quản, chế biến, tiêu thụ.

- Xúc tiến thương mại, mở rộng thị trường tiêu thụ sản phẩm, tháo gỡ những khó khăn trong tiêu thụ sản phẩm.

\subsection{Tranh thủ thò̀i co}

- Mở rộng thị trường tiêu thụ sản phẩm cam sành, sản xuất hướng đến xuất khẩu. Xây dựng chiến lược phát triển cam hàng hóa chất lượng cao theo hướng hiệu quả, bền vững. Hạn chế đến mức tối đa việc sử dụng các hóa chất trong sản xuất, bảo quản, chế biến sản phẩm. Sản xuất cam hàng hóa theo hướng xuất phát 
từ nhu cầu của thị trường, lấy thị trường làm căn cứ để xây dựng chiến lược quy hoạch vùng và sản xuất hàng hóa.

- Thu hút các nhà đầu tư để tăng cường các nguồn lực như vốn, khoa học kỹ thuật, máy móc thiết bị, trình độ quản lý... để mở rộng quy mô, phát triển vùng sản xuất cam hàng hóa, đầu tư ở tất cả các khâu: sản xuất, thu hoạch, chế biến, tiêu thụ.

- Tranh thủ cơ hội liên doanh, liên kết, hợp tác quốc tế trên nguyên tắc hội nhập, phát triển và cùng có lợi.

- Đẩy mạnh nghiên cứu, ứng dụng khoa học - kỹ thuật - công nghệ hiện đại, tiên tiến vào sản xuất, chế biến và tiêu thụ nông sản nhằm đảm bảo năng suất, chất lượng và hiệu quả kinh tế.

- Tăng cường đầu tư và hợp tác quốc tế trong đào tạo và phát triển nguồn nhân lực chất lượng cao phục vụ sự nghiệp phát triển nền nông nghiệp sản xuất hàng hóa hiệu quả, bền vững, hội nhập kinh tế quốc tế. Tăng cường các kiến thức pháp luật, ngoại ngữ, hội nhập kinh tế quốc tế, chú trọng bồi dưỡng năng lực tổ chức, quản lý, lãnh đạo.

\subsection{Vuột qua thách thức}

- Đảm bảo các tiêu chuẩn nghiêm ngặt đối với sản phẩm hội nhập như các yêu cầu về chất lượng, thương hiệu, vệ sinh an toàn thực phẩm, kiểu dáng mẫu mã, nguồn gốc xuất sứ, nhãn hiệu, bản quyền, quyền sở hữu trí tuệ, chống bán phá giá... Xóa bỏ tình trạng nông dân lạm dụng thuốc bảo vệ thực vật, thuốc trừ sâu, thuốc kích thích sinh trưởng, phân bón hóa học đối với sản phẩm cam sành. Tập trung phát triển sản xuất theo hướng hữu cơ, nông nghiệp sinh thái, bền vững.

- Phát triển hình thức sản xuất kinh doanh phù hợp, xây dựng các mô hình liên kết trong sản xuất và tiêu thụ cam sành, hình thành doanh nghiệp thu mua, bảo quản, chế biến và tiêu thụ sản phẩm để có thể thu gom sản lượng cam hàng hóa đủ lớn và ổn định đáp ứng yêu cầu xuất khẩu. Đẩy mạnh mô hình liên kết 4 nhà: Nhà nông, nhà quản lý, nhà khoa học, nhà doanh nghiệp trong sản xuất nông nghiệp nói chung và sản xuất cam sành nói riêng.

- Nâng cao năng lực cạnh tranh cho sản phẩm trong bối cảnh hội nhập: Nâng cao chất lượng sản phẩm, tăng năng suất, sản lượng, tiết kiệm chi phí sản xuất, hạ giá thành sản phẩm, xây dựng và quảng bá thương hiệu... là những giải pháp để nâng cao năng lực cạnh tranh của sản phẩm, không chỉ phải thành công trong chiến lược xuất khẩu mà còn phải cạnh tranh được với sản phẩm cùng loại nhập khẩu, được người tiêu dùng trong nước lựa chọn. Cần xúc tiến thương mại để mở rộng thị trường. Cần nắm bắt thông tin chính xác về nhu cầu của thị trường và khả năng cạnh tranh để làm cơ sở cho việc sản xuất sản phẩm.

- Để giảm bớt sự chênh lệch về trình độ phát triển với các nước thành viên của các hiệp định thương mại tự do, Việt Nam cần thực hiện chính sách "đi tắt, đón đầu” để tiếp thu những tiến bộ khoa học kỹ thuật, trình độ và kinh nghiệm quản lý, tăng cường hợp tác quốc tế trong đào tạo nguồn nhân lực chất lượng cao, thu hút các nguồn lực cho đầu tư phát triển. Mặt khác, nâng cao nhận thức và năng lực sản xuất kinh doanh của người nông dân.

- Phát huy quyền làm chủ của người dân khi tham gia hội nhập. Người dân trước hết phải có kiến thức về kinh tế thị trường, hiểu biết về hội nhập quốc tế, có thái độ ứng xử phù hợp với văn hóa sản xuất kinh doanh và luật pháp quốc tế, có trình độ quản lý kinh tế, tích lũy kinh nghiệm trong sản xuất kinh doanh, có trình độ khoa học kỹ thuật để áp dụng trong sản xuất, có lương tâm và trách nhiệm đối với sức khỏe cộng đồng và môi trường sinh thái, 
có đủ năng lực để làm chủ trên chính mảnh đất của quê hương mình. Chính quyền địa phương có những định hướng, hỗ trợ đào tạo, tập huấn, cung cấp đầy đủ, kịp thời các thông tin về thị trường, đối tác đầu tư kinh doanh, chính sách pháp luật Việt Nam và quốc tế có liên quan đến hoạt động sản xuất và tiêu thụ sản phẩm, giúp người dân tránh được những rủi ro.

\section{Kết luận}

Phát triển sản xuất sản phẩm cam sành theo hướng hội nhập cần được xác định là nhiệm vụ trọng tâm, mang tầm chiến lược trong kế hoạch phát triển kinh tế - xã hội của tỉnh Tuyên Quang. Đánh giá thực trạng sản xuất cam sành của tỉnh trong những năm qua cho thấy Tuyên Quang có rất nhiều tiềm năng, lợi thế cho phát triển sản xuất cam sành theo hướng hàng hóa. Tuy nhiên, trước thềm hội nhập kinh tế quốc tế, vẫn có rất nhiều những khó khăn, thách thức đặt ra trong sản xuất và tiêu thụ sản phẩm. Cần có sự quan tâm của các cấp, các ngành, các tổ chức xã hội - nghề nghiệp, người sản xuất, người tiêu dùng. Cần có sự vào cuộc và hợp tác, liên kết mạnh mẽ của bốn nhà: Nhà nước; Nhà khoa học; Nhà doanh nghiệp và Nhà nông, trong đó vai trò của doanh nghiệp đang thực sự cần thiết trong việc thu hoạch, bảo quản, chế biến, xây dựng thương hiệu và mở rộng thị trường tiêu thụ trong nước và xuất khẩu. Phát triển sản xuất sản phẩm cam sành của tỉnh Tuyên Quang theo hướng hội nhập yêu cầu phải đảm bảo vệ sinh an toàn thực phẩm tuyệt đối, đáp ứng nhu cầu, thị hiếu của người tiêu dùng, góp phần mang lại thu nhập ổn định cho người dân, đồng thời khẳng định vị thế của một trái cây đặc sản trong xu thế hội nhập và phát triển, góp phần thúc đẩy kinh tế của tỉnh Tuyên Quang ngày càng phát triển.

\section{TÀI LIỆ THAM KHẢO}

1. Cục thống kê tỉnh Tuyên Quang, Niên giám thống kê tỉnh Tuyên Quang 2015, Nhà xuất bản Thống kê, Hà Nội.

2. Chính phủ (2008), Quy hoạch tổng thể phát triển kinh tế xã hội tỉnh Tuyên Quang đến năm 2020, Quyết định số 100/QĐ-TTg ngày 15/7/2008.

3. FAO (2015). Top Production of Oranges, 2013. United Nations, Food and Agricultural Organization, FAO Statistics. 2013. Retrieved 21 June2015.

4. Phòng công nghiệp và thương mại Việt Nam VCCI (2015), Hồ sơ thị trường, http://vcci.com.vn/, 2015.

5. Sở Nông nghiệp và Phát triển Nông thôn tỉnh Tuyên Quang (2015), Báo cáo tổng kết tình hình sản xuất nông lâm nghiệp giai đoạn 2010 - 2015.

6. United States Department of Agriculture (2016), Citrus: World Markets and Trade, https://apps.fas.usda.gov/psdonline/circulars/citrus.pdf, July 2016.

7. Ủy ban nhân dân tỉnh Tuyên Quang (2014), Đề án Phát triển vùng sản xuất cam sành tỉnh Tuyên Quang, giai đoạn 2014-2020, Quyết định số 338/QĐ-UBND ngày 27/8/2014.

8. Hoàng Thanh Vân và CS (2015), Điều kiện tụ nhiên và tài nguyên thiên nhiên ảnh hưởng đến phát triển kinh tế - xã hội tỉnh Tuyên Quang, Tạp chí Khoa học \& Công nghệ, 65 (03): 39-43.

9. http://fruitvietnam.com/tin-tuc/kham-pha-14-loi-ich-tuyet-voi-tu-trai-cam.html, truy cập ngày 16/2/2017. 